\begin{tabular}{l}
\hline Nuansa Journal of Arts and Design \\
Volume 4 Nomor 2 September 2020 \\
e-ISSN: 2597-405X dan p-ISSN: $2597-4041$ \\
\begin{tabular}{|l|l|}
\hline (c) (1) This work is licensed under a Creative Commons Attribution \\
4.0 International License
\end{tabular} \\
\hline
\end{tabular}

\title{
NILAI-NILAI BUDAYA MAKASSAR DALAM KARAKTER TOKOH PERTUNJUKAN TEATER THE EYES OF MAREGE
}

\section{Asia Ramli}

\section{Corespondensi Author}

Prodi Pendidikan Seni Drama, Tari, dan Musik Fakultas Seni dan Desain Universitas Negeri Makassar

Email:

asiaramliprapanca@gmail.com

\begin{abstract}
ABSTRAK
Pertunjukan teater The Eyes of Marege kolaborasi Teater Kita Makassar dengan Australian Performing Exhange dipentaskan pada OzAsia Festival tanggal 27 - 29 September 2007 di Playhouse Adelaide, dan tanggal 5 - 7 Oktober 2007 di Studio Opera House, Sydney. Penelitian ini mendeskripsikan dan menganalisis fokus masalah: nilai-nilai budaya Makassar dalam karakter tokoh pada pertunjukan tersebut. Data dari jenis penelitian kualitatif ini diperoleh melalui observasi partisipatif, wawancara, dan dokumentasi. Hasil data dideskripsikan dan dianalisis berdasarkan pendekatan kebudayaan dan kajian semiotika teater. Adapun pola relasi antartokoh dianalisis dengan menggunakan model aktantial Greimas. Hasil menunjukkan bahwa karakter tokoh dalam pertunjukan teater The Eyes of Marege yang mewakili suku-bangsa Makassar mengandung nilai-nilai budaya Makassar, antara lain: nilai-nilai siri' na pacce, nilai-nilai tausipakatau, nilai-nilai pangngadakkang, dan nilai-nilai islam.
\end{abstract}

Kata kunci: teater, nilai budaya

\section{PENDAHULUAN}

Pulau Bimo, Arhemland, Northern Territory, 1905, di sudut kiri perahu Makassar yang bersandar di pantai, Djakapurra Munyarryun, putera kepala suku Yolngu (Aborigin) menyanyikan lagu Dji-li$l i$, Dji-li-li, Dji-li-li yang diperuntukkan kepada suku Makassar yang sedang berlayar dengan perahu menuju ke pantai itu. Lagu yang hanya bernada gumam menyayat itu, diiringi musik dedgeridoo (alat musik tiup yang terbuat dari batang kayu) khas Marege yang dimainkan oleh Leon Winambi anak suku Aborigin. Kelompok musik dari Makassar, sudah siap juga di situ, dengan alat musik daerahnya masing-masing. Manusia anjing merangkak, mengais, dan melonglong. Dhalawal, puteri suku Aborigin, menari bongol (tarian yang mengandalkan kaki dan tangan) menuju laut sambil menyanyi: 
Nilai-Nilai Budaya Makassar dalam Karakter Tokoh Pertunjukan Teater The Eyes Of Marege

Bergegas dari samudra, perahu tiba.

Layar hitam dinaikkan ke udara, mengoyak langit.

Sebuah perahu merah dibawa angin, menerjang ombak putih.

Perahu itu bersandar di air.

Pria-pria bersandar di perahu, menatap ke daratan.

Angin timur menjerit.

Angin musim menghembuskan hujan dari Indonesia,

dari Makassar ke Australia bagian Utara.

Setiap musim panas, awan-awan hitam berkumpul, bergetar bersama roh-roh guntur.

Banyak kisah menjelajahi laut Arafura, bercerita mengenai orang-orang Makassar orang-orang Yolngu dari Arnhemland.

Perahu-perahu ditiup angin musim. (Janson, 2007: 1)

Dari arah laut, orang-orang Makassar, Ahmad, Nud, dan Kasim, berlayar ditiup angin kencang. Mereka saling memanggil di laut. Mereka menyanyikan lagu Makassar. Lalu, tiba-tiba musik khas Makassar berubah menjadi musik khas Aborigin. Tarian "penjemputan" dari suku Aborigin dengan properti dayung bergerak. Orang-orang Makassar di atas perahu saling berteriak bersahut-sahutan dengan bahasa daerahnya: Panaungi sombalaka! Buangi jangkaraka! Layar telah dirunkan dan jangkar telah dibuang. Mereka pun turun ke pantai sambil menari dalam gerak-gerak ganrangbulo dan diiringi musik khas Makassar.

Kisah di atas merupakan cuplikan dari pertunjukan teater The Eyes of Marege kolaborasi Teater Kita Makassar dengan Australian Performance Exhance yang dipentaskan pada OzAsia Festival tanggal 27 - 29 September 2007 di Playhouse Adelaide, dan pada tanggal 5 - 7 Oktober 2007 di Studio Opera House, Sydney. Pendukung pertunjukan dari Makassar diwakili Ram Prapanca (sutradara dan pemeran tokoh Kasim), Ishakim (penata artistic dan pemeran tokoh Tetua Adat), Arifin Manggau (penata music), Hamrin Samad (penata gerak dan pemeran tokoh Nud serta pemeran tokoh Tetua Adat), Muhammad Ishaq (pemeran tokoh Ahmad), Solihing (pemusik). Adapun dari Yolngu diwakili Julie Janson (penulis naskah), Sally Sussman (sutradara), Bernadette Walong (Koreografer), Rod (pemeran tokoh Birramen), Lisa (pemeran tokoh Dhalawal dan tokoh Fatima), Djakapurra Munyarryun (pemeran tokoh Djandapurra dan Tetua Adat), Leon Winambi/Aaron (pemusik), Pepen (pemusik), Sam Hawker (administrator), Simon Wiser (manajer produksi), Kenny Chong (transportasi lokal).

Naskah The Eyes of Marege yang ditulis oleh Julie Janson dan diworkshopkan bersama Teater Kita Makassar di Baruga Colliq Pujie Fakultas Seni dan Desain Universitas Negeri Makassar memperlihatkan proses kolaborasi teater sebagai seni kolektif yang digali dari upacara ritual, seni tradisional, dan akar budaya dari dua suku-bangsa Makassar dan Yolngu. Kolaborasi teater ini mengangkat masalah hubungan sejarah, perdagangan, budaya, cinta, perkawinan, dan persaudaraan antara suku bangsa Makassar dengan suku bangsa Aborigin, yang pernah terjadi ratusan tahun lalu, dan mengandung nilai-nilai budaya lokal Makassar.

Mengingat pentingnya masalah seperti yang dipaparkan di atas, maka pada kesempatan ini peneliti akan meneliti dan membahas nilai-nilai budaya Makassar dalam karakter tokoh pada pertunjukan teater The Eyes of Marege kolaborasi Teater Kita Makassar dengan Australian Performance Exchange.

\section{METODE PENELITIAN}

Penelitian ini mendeskripsikan dan menganalisis fokus masalah: nilai-nilai budaya Makassar dalam karakter tokoh pada pertunjukan teater The Eyes of Marege kolaborasi Teater Kita Makassar dengan 
Australian Performance Exchange. Terkait dengan fokus penelitian, maka penelitian ini merupakan jenis penelitian kualitatif. Dalam mengumpulkan data, penelitian ini menggunakan teknik observasi partisipatif, yaitu peneliti pernah ikut berpartisipasi dan terlibat langsung dalam proses kolaborasi. Data lain yaitu berupa hasil wawancara yang pernah dilakukan oleh peneliti dengan penulis naskah, sutradara, dan aktor pendukung. Adapun dokumentasi berupa naskah drama, tulisan-tulisan di surat kabar, dan rekaman pertunjukan dalam bentuk diskografi DVD. Data yang telah diperoleh melalui observasi partisipasi, wawancara, dan dokumentasi, dideskripsikan dan dianalisis berdasarkan pendekatan kebudayaan dan kajian semiotika teater. Adapun pola relasi antartokoh dianalisis dengan menggunakan model aktantial Greimas.

Analisis data mengacu pada analisis data Miles dan Huberman (1994) yang menggambarkan tiga alir utama dalam analisis, yaitu: reduksi data, penyajian data, dan penarikan kesimpulan. Ketiga komponen analisis tersebut aktifitasnya dilakukan dalam bentuk interaktif dengan proses pengumpulan data sebagai suatu proses siklus (Rohidi, 2011: 233 - 240).

\section{HASIL PENELITIAN DAN PEMBAHASAN}

Tiga pakar semiotika teater berikut ini perlu sebagai awal titik tolak membahas pertunjukan teater The Eyes of Marege. Pertama, Jiri Veltrusky dalam artikelnya "dramatic text as component of theatre" (1976, 1941) menyatakan bahwa 'teks dramatik' (baca 'naskah lakon') merupakan komponen teater. Veltrusky adalah pelopor yang merintis jalan untuk mencari tahu hubungan antara sistem tanda linguistik pada teks dramatik dan sistem tanda pada 'teks pertunjukan' sebagai konteks pementasannya. Maka, untuk memahami makna teks dramatic diperlukan pemahaman makna teks pertunjukannya. Begitu pula sebaliknya. Kedua, Keir Elam pada bagian akhir di dalam bukunya The Semiotics of
Theater and Drama sampai pada kesimpulan, bahwa memang ada dua bidang penting yang perlu dikaji untuk memahami drama dan teater sebagai tanda, yaitu teks dramatic dan teks pertunjukan (Elam, 1980: 208). Ketiga, Elaine Aston dan George Savona dalam buku mereka yang berjudul Theatre As Sign-Symtem: A Semiotics of Text and Performance memandang bahwa teater adalah sebuah wacana teks yang kompleks dan rumit. Dalam kedudukannya sebagai sebuah teks, teater berfungsi sebagai suatu sistem tanda. Untuk memahami arti dan/atau makna teater diperlukan analisis teater yang meliputi dua bidang kajian, yaitu teks dramatik (dramatic text) dan teks pertunjukan (performance text) (Aston 1991:8. lihat Satoto, 1994:6-25).

Berdasarkan struktur teks dramatic (cerita, tokoh, dialog) dan teks pertunjukan (set panggung, pemeranan, karakter, kostum, properti, musik dan lagu) dalam kajian semiotika teater, pertunjukan teater The Eyes of Marege merupakan bentuk drama derision (drama absurd) atau bisa juga disebut drama surealis. Drama ini terdiri dari dua babak, dan pergantiannya hanya ditandai dengan munculnya pemeran Dhalawal (pembawa berita) dan munculnya para pemeran nelayan Makassar di atas bagang (yang menyimbolkan perahu). Pergantian adegan ditandai oleh pergantian atau perubahan musik yang dimainkan oleh pemusik di bawah bangang. Bagang mempunyai multifungsi. Secara semiotis, bagang mempunyai makna ikonis, indeksikal, maupun simbolis, bergantung pada pemeran dalam memanfaatkannya sebagai sistem tanda yang memiliki kesadaran situasi komunikatif, signifikan, atau tidak. Demikian halnya dengan beberapa property yang digunakan terutama pada property yang digunakan oleh pemeran tokoh dari Makassar.

Sebagai sistem tanda, tokoh-tokoh, pemeran dan karakter juga sering berubahubah, tergantung dari suasana dan peristiwa yang dibangun. Drama ini digarap di atas panggung seperti teater rakyat Makassar. Semua pemain dan pemusik berada di atas panggung dengan posisinya masing-masing. 
Nilai-Nilai Budaya Makassar dalam Karakter Tokoh Pertunjukan Teater The Eyes Of Marege

Ketika perubahan tokoh dan pemeran, para pemain mengganti kostum di atas panggung dan dapat dilihat langsung oleh penonton. Setting Makassar dan Yolngu lewat set, property dan para tokoh di atas panggung dibiarkan nampak dan menyatu. Perubahannya yaitu pada pergantian babak dan adegan melalui pemeranan, dialog, musik, nyanyian dan tarian.

Bahasa dan dialog yang digunakan di atas panggung lebih dominan bahasa Inggeris dan Indonesia seseuai dengan latar peristiwa dan kepada siapa dialog ditujukan. Sedang bahasa Makassar, Yolngu, dan Arab dipakai selain digunakan lewat dialog, juga digunakan lewat nyanyian atau lagu dengan iringan musik dan tari.

Drama The Eyes of Marege dengan latar tahun 1905 ini mengambil setting Makassar, Sulawesi Selatan, Indonesia, dan pulau Bimo, Arnhamland (Northern Territory), bagian utara Australia. Drama ini terdiri dari dua babak dan masing-masing babak terdiri enam adegan. Adapun struktur pertunjukan dideskripsikan sebagai berikut:

Tahap awal yang merupakan pengenalan atau eksposisi, digambarkan kedatangan orang-orang Makassar sebagai nelayan dan pedagang ke Pulau Bimo yang sudah berlangsung ratusan tahun dan telah melahirkan rasa persaudaraan dan bahkan ikatan perkawinan di antara orang Makassar dengan orang Yolngu.

Tahap komplikasi yang merupakan penggawatan atau perumitan, dilukiskan ketika pria muda Yolngu bernama Birramen membunuh nelayan Makassar bernama Kasim karena membela diri. Pasalnya, tas "keramat" milik Birramen yang tertinggal di pantai ditemukan (dicuri) oleh Kasim dan telah membentuknya menjadi keranjang perangkap ikan. Karena tas itu baginya bukan tas biasa melainkan tas upacara inisiasinya yang penuh roh dan impiannya, Birramen mengambil paksa tas itu dari tangan Kasim. Diperlakukan begitu, Kasim menganggap Birramen seorang pencuri yang melanggar hukum Allah. Kasim menyerang Birramen dengan badiknya.
Birramenpun mengeluarkan tombaknya sehingga terjadi pertarungan sengit. Kasim tertusuk, jatuh, dan meninggal. Para tetua Yolngu dan orang-orang Makassar sepakat Birramen diadili di Makassar. Ahmad, saudara sepupu Kasim, yang sudah seperti bersaudara dengan Birramen, mengantar Birramen ke Makassar untuk diadili. Dhalawal adik Birramen, perempuan Yolngu, kekasih dan sudah menjadi istri Ahmad, sangat sedih atas kejadian itu dan khawatir dengan kepergian kakaknya dan suaminya.

Tahap penyelesaian yang merupakan puncak laku, klimaks atau saat yang menentukan, yaitu Pengadilan Makassar memutuskan hukuman 1 tahun penjara bagi Birramen. Sebelum menjalani hukuman, Birramen berkenalan dengan perempuan Makassar bernama Fatima dan mereka saling jatuh cinta. Selepas menjalani masa tahanan, Birramen dan Fatima menikah secara Islam. Ahmad mengantar Birramen kembali ke Pulau Bimo dan menemui Dhalawal, istrinya. Tiba di Pulau Bimo, mereka tidak bisa lagi berlabuh dan mendaratkan kakinya ke Marege. Sebab polisi-polisi perairan Australia menembaki mereka. Orang-orang Makassar dilarang berdagang dan menyelam mencari tripang. Hanya Birramen yang bisa turun ke pantai itu. Orang-orang Yolngu berkumpul di pantai itu bersama Birramen, Dhalawal dan Djandapurra dengan perasaan sedih, sementara orang-orang Makassar berlayar meninggalkan pantai kembali ke Makassar.

\section{Pola Relasi Antartokoh}

Tokoh cerita dalam pertunjukan teater seringkali disebut sebagai penokohan yang berwatak atau berkarakter. Istilah 'karakter' menjadi padanan istilah 'tokoh' yang berarti 'tokoh - yang ber - watak', artinya tokoh yang hidup, berjiwa atau berroh, bukan tokoh mati. Untuk selanjutnya dalam tulisan ini digunakan istilah 'tokoh' yang dapat diturunkan ke dalam bentuk kata 
'penokohan', 'perwatakan', atau karakterisasi'.

Istilah 'karakter' berasal dan bahasa Yunani 'kharakter berarti tiga prinsip yang dihubungkan dengan kumpulan ide-ide. Salah satu prinsip di antaranya adalah pengertian metaforikal 'tanda', atau 'tanda yang memberi kesan' pada seseorang atau sesuatu, sebuah 'karakteristik' atau 'tanda khusus'. Terjemahannya yang pertama digunakan dalam bahasa Inggris untuk menunjukkan 'suatu kepribadian dalam suatu novel atau suatii lakon pada tahun 1749 (Aston 1991:34; Cf Hawkes 1977:68-9).

Dalam hubungannya dengan fungsi tokoh, Propp telah mengamati bahwa salah satu tokoh benar-benar cocok dengan kekuatan/tindakan/lakuan, atau tokoh itu mengubah fungsinya dengan jalan melibatkan beberapa bidang kekuatan, atau satu bidang kekuatan dibawakan oleh beberapa tokoh (Propp 1975:79-83; lihat juga Aston 1991:36). Meskipun naratologi Propp hanya terbatas pada cerita dongeng Rusia, tapi gagasan penggabungan bidangbidang kekuatan pada tokoh dapat diaplikasikan untuk menganalisis fungsi tokoh pada lakon drama. Bertolak dari analisis fungsi tokoh yang dikemukakan Propp, Greimas dalam Taum (2011: 144. lihat juga Effendy, 2005) merumuskan enam fungsi tokoh yang kemudian dikenal sebagai model aktantial Greimas (actantial model: Greimas). Perhatikan diagram di bawah ini.

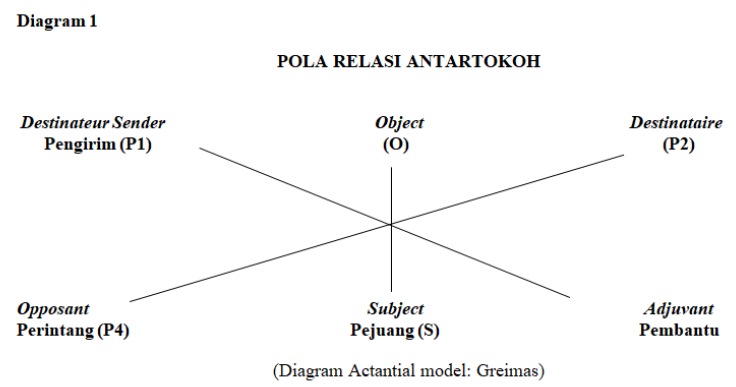

Skema di atas, pengirim $\left(\mathrm{P}_{1}\right)$ adalah suatu kekuatan pendorong yang berpengaruh dan mewarnai kekuatan pada subjek (S) yang bergerak mencari keberadaan objek (O) untuk kepentingan si penerima $\left(\mathrm{P}_{2}\right)$. Dalam $\mathrm{S}$ mencari $\mathrm{O}$, ia $(\mathrm{S})$ dapat dibantu oleh kekuatan $\left(\mathrm{P}_{3}\right)$, atau mungkin ditentang oleh kekuatan lain yaitu penentang $\left(\mathrm{P}_{4}\right)$. Maka terjadilah interaksi antar kekuatan sehingga menimbulkan konflik antar tokoh. Dalam proses perkembangan alur dramatik, ada kemungkinan terjadi alih fungsi antar kekuatan tokoh, sehingga konflik berkembang pula secara dinamis. Di bawah ini merupakan aplikasi model aktan Greimas tentang pola relasi antartokoh pada pertunjukan teater The Eyes of Marege.

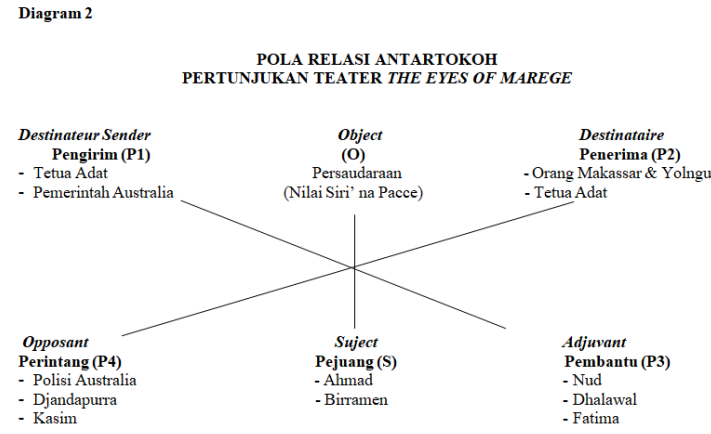

Diagram di atas menunjukkan tokoh Subjek (S) Ahmad dan Birramen berjuang memegang teguh (O) yaitu ikatan persaudaraan dan perkawinan yang mengandung nilai siri' na pacce bagi sukubangsa Makassar dan Yolngu. Persaudaran dan ikatan perkawinan (O) telah diterima secara harmonis oleh kedua suku-bangsa (P2). Dalam memperjuangkan (O), Ahmad dan Birramen (S) dibantu oleh oleh Dhalawal dan Nud (P3). Tapi dalam memperjuangkan $\mathrm{O}$ ), mereka mendapat rintangan (P4) dari Djandapurra dan Kasim. Tapi rintangan ini hanya gangguan dari dalam yaitu dari dua suku-bangsa Makassar dan Yolngu. Rintangan keras, datang dari luar, yaitu Polisi Australia Bagian Selatan (P1) sebagai kekuatan tersembunyi, dengan menembaki dan mengusir orang Makassar dari Marege. Diagram berikut ini menggambarkan perubahan relasi antartokoh:

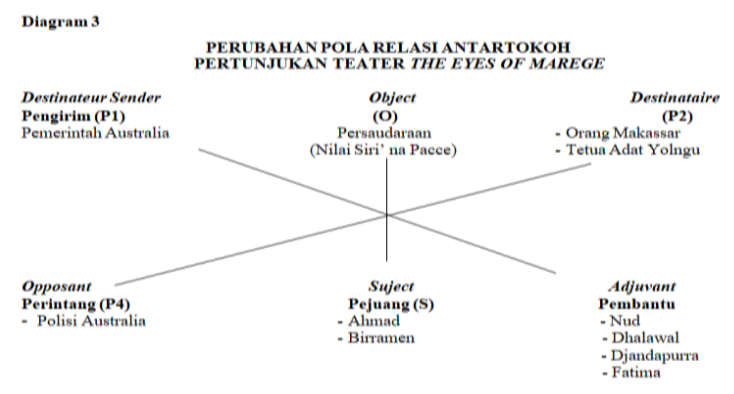


Nilai-Nilai Budaya Makassar dalam Karakter Tokoh Pertunjukan Teater The Eyes Of Marege

Berdasarkan diagram di atas, dalam perkembangan lakon menunjukkan perubahan pola relasi antartokoh. Tokoh Djandapurra (P4), setelah pertikaian ringan di babak 1 adegan 2, ia menjadi tokoh yang menempati (P3), sedang Kasim tidak lagi muncul karena sudah meninggal. Demikian halnya dengan tokoh Tetua Adat, dalam perkembangan kisah, mereka tidak lagi menempati (P1) karena kekuasaan telah dipegang oleh Polisi Australia. Dengan demikian, Tetua Adat berubah menempati (P2) bersama orang Makassar dan Aborigin. Artinya kalau perjuangan persaudaraan itu berhasil dan tidak dirusak oleh Polisi Australia Bagian Selatan, mereka juga akan menikmati hasilnya, yaitu hubungan persaudaraan akan tetap berjalan secara harmonis. Karena Polisi Australia selaku wakil dari pemerintah kulit putih yang sedang berkuasa (P1) mengirim pesan "pengusiran" dengan menembaki dan membakar perahu-perahu orang Makassar serta melarang berdagang dengan orang Aborigin, maka mereka akhirnya satusatunya menempati posisi $(\mathrm{P} 4)$ sebagai perintang besar.

\section{Nilai-nilai Budaya Makassar}

Secara umum, Wahid (2008:44-45) mengemukakan, bahwa nilai-nilai budaya mengandung nilai berguna benar (nilai kebenaraan), nilai-nilai keindahan (estetik), dan nilai-nilai agama (relegius). Nilai-nilai budaya ini, merupakan sesuatu yang tidak hanya sesuatu yang berwujud benda material saja, tetapi juga sesuatu yang berwujud benda abstrak. Sesuatu yang abstrak itu dapat mempunyai nilai yang sangat tinggi dan mutlak bagi manusia. Dalam pelaksanaannya, nilai-nilai ini dijabarkan dalam bentuk kaidah atau ukuran, sehingga merupakan suatu perintah atau keharusan, anjuran, atau merupakan larangan yang tidak diinginkan.

Nilai-nilai budaya Makassar menurut Wahid (2008: 65) tidak terlepas dari konsep kebudayaan Makassar yang berlandaskan falsafah siri' na pacce yang dipegang teguh pada setiap kata dan perbuatan. Siri' (harga diri dan kehormatan keluaraga) dan harus ditegakkan bersama-sama secara timbalbalik Sedangkan pace (sedih, perih), rasa yang paling dalam untuk saling menyempurnakan niat baik. Matthes (dalam Rahim, 1992: 169) mencatat arti siri' dengan tujuh buah kata bahasa Belanda, yaitu beschaamd, schroomvallig, verlegen, schaamte, eergevoel, schande, wangunst, dan mengikut urutannya diterjemahkan sebagai: amat malu, dengan malu, malu sebagai kata sifat atau kata keadaan, perasaan malu menyesali diri, perasaan harga diri, noda, aib dan dengki. Menurut Rahim (1992: 169), siri' disejajarkan kedudukannya dengan akal pikiran yang baik karena bukan timbul dari kemarahan, dengan peradilan yang bersih karena tidak dilakukan dengan sewenang-wenang, dengan perbuatan kebajikan yang tidak menjelekkan sesama manusia secara tak patut.

Basya dan Mustaring (dalam Wahid, 2008: 62-63) mengemukakan tiga pengertian tentang siri', yaitu: (1) Siri' itu sama dengan malu, isin (jawa), shame (inggris); (2) Siri' itu merupakan daya pendorong untuk melenyapkan, mengasinkan mengusir, dan sebagainya terhadap siapa saja yang menyinggung perasaan mereka. Hal ini merupakan kewajiban adat. Yaitu hukuman menurut norma-norma adat jika tidak dilaksanakan; (3) Siri' sebagai daya pendorong yang bisa juga ditujukan ke arah pembangkitan tenaga untuk membanting tulang, bekerja mati-matian, demi suatu pekerjaan atau usaha.

Hamka mengemukakan bahwa siri' itu menimbulkan tawadhu dan perangai terpuji yaitu mahmudah 'perbuatan mulia' yang terdiri atas: (1) Sabar, yaitu dapat mengendalikan diri ketika sedang marah, (2) Iffah, artinya dapat menahan nafsu ketika hendak didorongkan, (3) Syajaah, artinya berani karena benar dan yakin serta sanggup mempertahankan di mana saja, (4) Adil artinya pertengahan (sitaba-taba). Kesimpulan menurut Islam, siri' itu berkaitan erat dengan orang yang beriman 
dan berakhlak tinggi. Selanjutnya, Budidarmo mengemukakan bahwa siri' adalah pandangan hidup yang mengandung etik perbedaan antara manusia dengan binatang. Siri' mengajarkan moralitas kesesuaian yang berupa anjuran, larangan, hak, dan kewajiban manusia untuk bertindak, menjaga dan mempertahankan harga diri dan kehormatan. Siri' adalah proses endapan kaidah-kaidah yang diterima dan berlaku dalam lingkungan masyarakat mengalami pertumbuhan berabad-abad sehingga membudaya (dalam Wahid, 2008: 63-64).

\section{Nilai-nilai Budaya Makassar dalam Karakter Tokoh}

Pada bagian ini akan dikemukakan nilai-nilai budaya Makassar yang dipresentasikan oleh tokoh (watak, peran) berdasarkan teks dramatik (cerita, tokoh, dialog) dan teks pertunjukan teater (set panggung, pemeranan, karakter, kostum, properti, musik dan lagu) dalam pertunjukan teater The Eyes of Marege kolaborasi Teater Kita Makassar dengan Australian Performance Exhange.

\section{Nilai-nilai Siri’ na Pacce}

Pertunjukan teater The Eyes of Marege membawa nilai-nilai siri' na pace (harga diri dan kehormatan), yaitu sebagai daya pendorong yang bisa juga ditujukan ke arah pembangkitan tenaga untuk membanting tulang, bekerja mati-matian, demi suatu pekerjaan atau usaha. Secara tersirat metafora siri paccea rikatte, kontu ballak ia benteng, ia patongko, ia todong jari rinring, selalu dibawa oleh tokoh dan karakter Ahmad. Dia merupakan wakil dari orang Makassar yang menjunjung tinggi nilai siri' na pacce. Baginya siri' na pacce ialah sesuatu yang amat berharga bagi manusia yakni harga diri. Karena tahu tentang siri'nya, dan tidak mau malu pada masyarakat dan keluarga, ia bersama orang-orang Makassar yang lain berjuang mencari kehidupan dengan berlayar mengarungi laut ke Arnhemland. Selain menyelam mencari tripang, meraka juga berdagang, bersosialisasi, menyesuaikan diri sebagai manusia pembangun. Mereka membawa peradaban yang lebih baik dari suku bangsa Yolngu, termasuk membangun industri tripang pertama di dunia. Mereka menjadi sumber inspirasi perjuangan, dan pendorong serta pengarah bagi setiap anggota masyarakat Yolngu.

Islam telah membawa tokoh Ahmad menjadi seorang yang taat beribadah di darat maupun di tengah badai di laut. Kuantitas ibadahnya merupakan kuantitas siri'-nya juga, sehingga kualitas kemanusiaannya terjaga dengan baik. Siri' dia tegakkan secara timbal-balik, menjaga siri'-nya dan menjaga siri' orang lain. Hal ini tersirat dalam babak 1 adegan 2 ketika dia berhadapan dengan Djakapurra. Dia mempertahankan siri'nya kerena menyangkut martabat dan harga dirinya sebagai manusia dan dalam lingkungan hidup masyarakat. Dia mempertahan janjinya kepada Dhalawal kekasihnya yang pernah diucapkan di hadapan keluarga Dhalawal. Tapi dia juga tetap menghormati keluarga Dhalawal. Ahmad syajaah, artinya berani karena benar dan yakin serta sanggup mempertahankan di mana saja.

Siri' tidak bersifat menentang saja, tetapi juga merupakan perasaan halus dan suci. Hal ini diekpresikan oleh Ahmad dengan memberikan hadiah-hadiah kepada Djandapurra dan orang-orang Yolngu lainnya. Dia juga secara halus menyampaikan kepada Dhalawal untuk pulang ke rumah memberitahukan orang tuanya tentang perjanjian mereka dahulu (babak 1 adegan 2).

Pada babak 1 adegan 2, dan pada saat kematian Kasim, pamannya, memperlihatkan bahwa dalam setiap mengahadapi masalah, Ahmad selalu sabar dan mamupu mengendalikan diri ketika sedang marah. Dia dapat menahan nafsu ketika hendak didorongkan (iffah). Dia berani karena benar dan yakin serta sanggup mempertahankan di mana saja (syajaah). Selain itu ia juga adil dan menjadi penengah (sitaba-taba). Siri' seperti ini adalah sesuatu yang tawadhu dan perangai terpuji yaitu mahmudah (perbuatan mulia). Siri' seperti ini berkaitan erat dengan 
Nilai-Nilai Budaya Makassar dalam Karakter Tokoh Pertunjukan Teater The Eyes Of Marege

orang yang beriman dan berakhlak seperti dalam kehidupan Ahmad.

Perkawinan Birramen dengan Fatima merupakan contoh nilai-nilai siri' yang di dalam lontarak dianjurkan untuk ditegakkan bersama-sama secara timbal-balik. Pertemuan pertama yang tidak terduga di pasar tradisional Makassar telah menanam rasa persaudaraan, cinta, kasih sayang dan disempurnakan dalam kehidupan suami-istri berdasarkan pertimbangan, seiring sekehendak kedua keluarga. Ajaran tentang saling menjaga siri' (malu) dari semua perbuatan yang appakasiri' (membuat malu), justeru diperoleh di tengah pergaulannya sehari-hari, baik di atas perahu, di pasar, di mesjid, dan bahkan di dalam penjara. Sebagai suami istri, siri' suami harus dijaga oleh istri dan begitu pun sebaliknya.

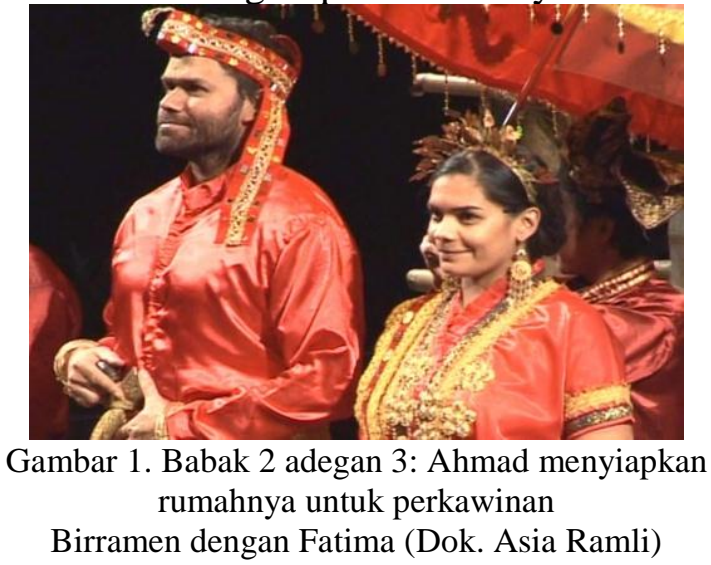

Bagi Birramen, siri' telah menjadi dirinya untuk menjaga dan mempertahankan harga diri dan kehormatannya. Nilai-nilai abstrak ini merupakan proses pendidikan dan peradaban baru bagi Birramen dan dibawa serta bersama pakaian pengantin kebesaran sultan Makassar di atas perahu dagang bermuatan gula merah, asam jawa, rokok, kain sutra, juga bahasa, tarian, dongeng, mitos, sejarah, cinta, dan persaudaraan ke tanah Armhemland. Proses semacam ini merupakan proses endapan kaidah-kaidah yang diterima dan berlaku dalam lingkungan masyarakat dan mengalami pertumbuhan berabad-abad sehingga membudaya. Di samping nilai siri', terdapat lagi semacam nilai yang disebut pacce. Secara leksikal pacce berarti pedih, perih. Konsep siri' dan pacce amat sulit dipisahkan namun dapat dibedakan. Kuantitas pacce yang dimiliki seseorang menentukan kualitas yang bersangkutan di mata sesama manusia dan di depan Allah.

Pertunjukan teater The Eyes of Marege, tersirat nilai-nilai pacce yang menyiratkan metafora paccei parrukku (perih ususku) yang memiliki makna ganda. Erokak aklamba-lamba ka paccei parrukku (saya ingin makan pagi (sarapan) karena lapar, tersirat dalam ucapan Nud di atas perahu dan ketika tiba di Makassar. Sedangkan paccei parrukku anciniki tau natabaya bola (iba hati saya melihat orang yang ditimpa musibah) yang mendorong seseorang melakukan sesuatu untuk membantu karena rangsangan dari pace (rasa yang dalam) tersirat pada babak 1 adegan 2 , 3, 5, 6, dan babak 2 adegan 1, 2, 3, 4, 5. Nilai pangngalik, schroom (segan), sipangngaliki (saling menghormati) terdapat pada tokoh Ahmad, Dhalawal, Birramen, Djandapurra, Nud, orang-orang Makassar dan Yolngu dan orang-orang di pengadilan. Nilai-nilai yang merupakan salah satu dari wujud sipakatau (saling menganggap manusia) ini, mereka aktualisasikan dalam babak 1 adegan 2, 3, 5, 6, dan babak 2 adegan 1, 2, 3, 4, 5, 6. Dalam kehidupan orang Makassar sering terdengar ujaran: punna erokko nipangngaliki, pangngaliki rong taua (jika ingin dihormati, hormatilah orang terlebih dahulu). Metafora ini tersirat dalam perangai tokoh Makassar pada babak 1 adegan 2, 3, 5, dan babak 2 adegan 1, 2, 3, 4, 5, 6 .

\section{Nilai - nilai tau - sipakatau}

Dalam kehidupan masyarakat, orang Makassar berpegang pada nilai - nilai tau yang disebut sipakatau, sikap budaya yang merupakan inti atau pangkalan sikap keterbukaan yang berarti saling membuka diri dalam peranan hidup kemausiaan. Sikap ini dibawa oleh tokoh, peran, dan karakter Ahmad sebagai simbol mewakili orangorang Makassar yang berkarakter protagonis (baik atau ideal). Dengan bertolak dari 
budaya sipakatau inilah, secara tersirat diwujudkan dalam interaksi sosial baik di Arnhemland maupun ketika di Makassar. Dan ini berlangsung sesuai dengan nilai nilai ideal kebudayaan yang terdapat dalam sistem budaya Makassar.

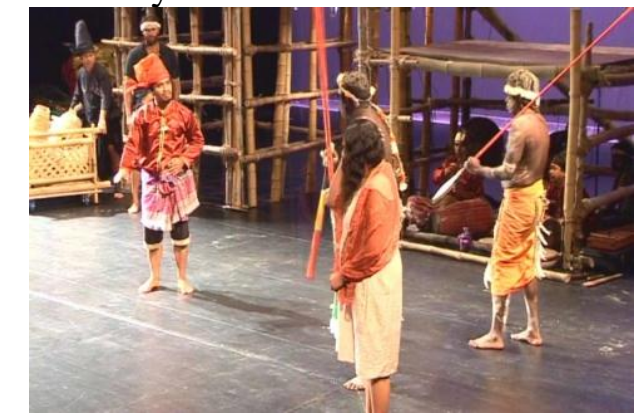

Gambar 2. Babak 1 adegan 2: Tokoh Ahmad menunjukkan dirinya sebagai tokoh protagonis yang membawa nilai "manusia benarbenar manusia” (Dok. Asia Ramli)

Konsep tentang tau 'manusia' tersirat dalam dialog, tokoh, pemeran dan karakter Ahmad pada babak 1 adegan 2, 5, dan babak 2 adegan $1,2,3,4,5,6$, yang mendeskripsikan orang yang dapat dipercaya dan diandalkan. Pada babak 1 adegan 2, 3, 5, babak 2 adegan 1, 2, 3, 4, 5, 6, yang mendeskripsikan orang yang memiliki tanggung jawab, rasa kesetiakawanan, dapat menghargai orang lain, dan memiliki adat dan sifat sopan santun. Pada babak 1 adegan pada adegan 2, 5, babak 2 adegan 1, 2, 3, 4, 5 , 6, yang mendeskripsikan orang yang selalu tepat ramalan dan orang yang ucapannya sering terbukti. Pada babak 1 adegan 2, 3, 5, babak 2 adegan 1, 2, 3, 4, yang mendeskripsikan orang yang taat beragama. Pada babak 1 adegan adegan 2, 3, 5, dan babak 2 adegan 1, 2, 3, 4, 5, 6, yang mendeskripsikan orang yang dapat dimintai pertimbangan. Pada babak 1 adegan 2, 3, 5, dan babak 2 adegan 1, 2, 3, 4, 5, 6 yang mendeskripsikan orang yang tidak menampakkan kehebatannya. Pada babak 1 adegan 2, 3, 5, dan babak 2 adegan 1, 2, 3, 4, 5 , 6, yang mendeskripsikan orang yang senang menerima nasihat. Pada babak 1 adegan 2, 3, 5, dan babak 2 adegan 1, 2, 3, 4, 5,6 , yang mendeskripsikan orang yang berwibawa dan dapat didengar nasihatnya. Pada babak 1 adegan pada adegan 2, 3, 5, babak 2 adegan 1, 2, 3, 4, 5, 6, yang mendeskripsikan orang disegani dan dihormati karena kewibawaannya. Pada babak 1 adegan 2, 3, babak 2 adegan 1, 2, 3, 4, 5, yang mendeskripsikan orang yang bahagia kehidupannya. Konsep tentang tau 'manusia' tersirat juga dalam dialog, tokoh, pemeran dan karakter Dhalawal, Birramen, Djandapurra dan orang-orang di pengadilan.

Nilai-nilai budaya Makassar yang mengandung nilai "ada manusia yang sekedar manusia" tersirat dalam tokoh Nud, pada babak 1, adegan 2, yang menggambarkan dirinya yang hanya asal bicara saja dengan membangga-banggakan foto kekasihnya yang tidak jelas, yang merupakan hanya bayangan saja bagi orang lain. Ia selalu mengagumi Belanda dan bercita-cita menjadi anak mantu Gubernur Makassar. Sesuatu yang tidak masuk akal menurut orang lain. Pada adegan 6, tersirat Nud sebagai manusia yang yang hanya berkelakar, main-main. Orang Makassar menyebutnya poro tau (sekedar manusia).

Kasim, pada bab 1 adegan 5, digambarkan sebagai orang yang didengarkan bila berbicara, namun pembicaraannya tidak dipercaya oleh Ahmad dan Birramen. Bila dikaitkan dengan pengetahuan tentang manusia, diketahui bahwa yang membedakan antara manusia dengan makhluk yang lain ialah kemampuan berbicara, maka Kasim dianggap hanya sebagai seorang manusia yang memiliki kemampuan berbicara tapi tidak mempunyai tanggung jawab, tidak memiliki kejujuran dan kesopanan. Orang seperti ini dianalogikan dengan manusia yang oleh orang Makassar dikatakan akkananaji no tau (disebut orang karena ia dapat berbicara).

Perangai buruk (antagonis) di atas tersirat juga dalam tokoh, peran dan karakter pria Makassar yang hendak membawa Birramen ketika tiba di Makassar sebelum dibawa ke mesjid dan pengadilan. Sedangkan perangai buruk tau tea nikabbiliki (orang yang tidak mau dicubit yang mendeskripsikan orang yang kikir) disandang Nud ketika memperlihatkan kekecewaannya saat Ahmad memberikan beras kepada Djakapurra (babak 1 adegan 2). 
Nilai-Nilai Budaya Makassar dalam Karakter Tokoh Pertunjukan Teater The Eyes Of Marege

Perangai buruk yang lain disandang oleh polisi-polisi perairan Australia yang mengusir orang-orang Makassar dari Arnhemland dengan memporak-porandakan kemah-kemah dan panci-panci, menembaki dan membakar perahu orang-orang Makassar.

\section{Nilai Pangngadakkang}

Dalam pertunjukan The Eyes of Marege tersirat nilai pangngadakkang berdasarkan metafora budaya Makassar tau tangngasseng pangngadakkang (orang yang tidak tahu aturan adat) yang mendeskripsikan seseorang yang dalam pergaulan sosial tidak dapat menyesuaikan diri dengan adat-istiadat setempat. Metafora ini tersirat pada tabiat Kasim dalam babak 1 adegan 5. "Tas inisiasi" sebagai simbol upacara ritual bagi suku bangsa Yolngu, tapi Nud karena ketidakpengetahuannya, malah dijadikan sebagai alat perangkap ikan. Selain itu, metafora budaya Makassar tau ammallaki pangngadakkang (orang yang memiliki dan mengetahui aturan adat) yang mendeskripsikan orang yang tahu secara tepat mengenai waktu, tempat dan sasaran suatu aturan adat, tersirat pada tokoh Ahmad mulai pada babak 1 , adegan 2,3 , 5, dan babak 2 adegan 1, 2, 3, 4, 5, 6). Tersirat juga pada tokoh Fatima pada babak 2 adegan 2, dan pada tokoh Birramen setelah ia mendapatkan ajaran budaya dan ajaran Islam di Makassar. Metafora ini tersirat kental pula pada orang-orang yang mengadili Birramen. Selain itu, juga tersirat pada tokoh-tokoh Yolngu, yaitu Dhalawal dan Djandapurra dengan nilai-nilai adat daerahnya, Yolngu.

Awak perahu The Eyes of Marege memilki prinsip yang dianut oleh orangorang Makassar, yaitu Adakaji tojeng iaji ranrang tatappu, ia barang bawang, mannanjo natunrung barak. (Orang yang memegang adat kebiasaan negeri, menemukan di dalamnya sebuah tali jangkar yang tidak putus dan tidak akan bergeser dari tempatnya ditambatkan, meskipun perahu dihantam amukan badai dahsyat). Prinsip ini tersirat dalam tokoh Makassar, antara lain pada babak 1 adegan 1, 2, 3, 5, 6, dan babak 2 adegan 1, 2, 3, 4, 5, 6. Metafora tersebut dipresentasikan dengan menurunkan tali merah dari perahu orang Makassar ke pantai Marege, dan melalui tali merah itu mereka menurunkan benda-benda budaya Makassar untuk orang Aborigin. Demikian halnya orang Aborigin, melalui tali merah itu, mereka menaikkan benda-benda budayanya ke atas perahu. Sebuah simbol ikatan nilainilai budaya yang tak akan pernah putus.

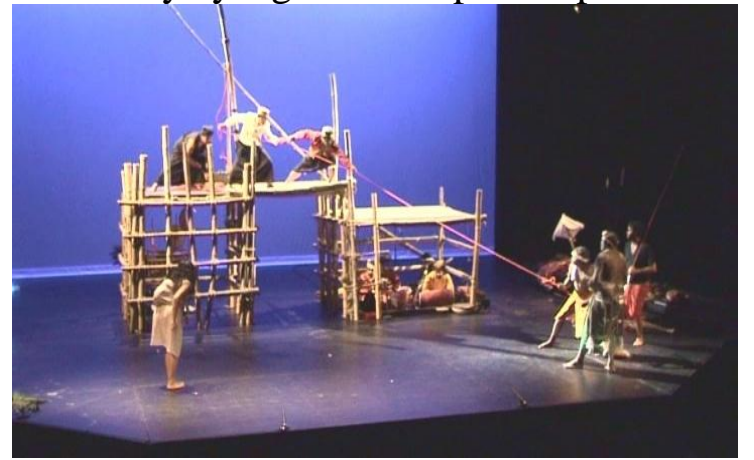

Gambar 3. Babak 2 adegan 5: Tali merah sebuah simbol ikatan yang tak akan pernah putus (Dok. Asia Ramli)

Pada babak 1 adegan 2, kedua suku bangsa berseteru mempertahankan adat masing-masing, tapi setelah dipertimbangkan kepatutan, pembedaan dan penyerupaan masing-masing, maka yang diputuskan adalah juga nilai-nilai yang mengandung kebenaran. Pada babak 1 adegan 5, ketika Birramen membunuh Kasim dalam kasus "tas inisiasi", Birramen diputuskan oleh adat untuk diadili di Makassar. Kasim pun dimakamkan secara adat dari dua suku bangsa tersebut.

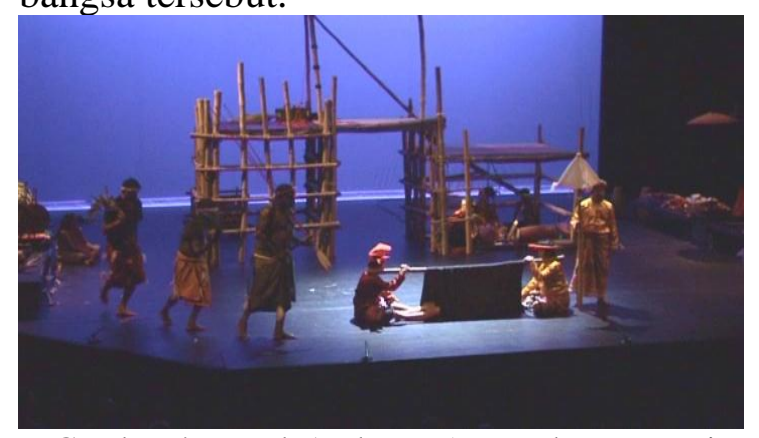

Gambar 4. Bapak 1 adegan 5: Pemakaman Kasim dilakukan secara Islam-Makassar, dan orang Aborigin ikut dalam upacara pemakaman itu dengan cara budaya mereka juga sebagai tanda penghormatan terhadap arwah Kasim (Dok. Asia Ramli) 


\begin{abstract}
Ketika Birramenen diadili di Makassar, pengadilan adat juga yang memutuskan hukuman lima tahun di penjara. Dan pada saat Birramen keluar dari penjara, ia pun dikawinkan dengan Fatima secara adat. Hampir semua proses adegan dalam The Eyes of Marege bernuansa adat. Proses adat semacam ini merupakan suatu sistem kebudayaan yang menggariskan ketentuan bagi segenap sikap dan tingkah laku yang diketahui, dimiliki dan dipertahankan sebagai milik bersama. Mereka yang mematuhinya akan memperoleh penghargaan dan akan memperoleh hukuman bagi yang melanggarnya.
\end{abstract}

\section{Nilai-nilai Islam}

Pertunjukan The Eyes of Marege sarat dengan nilai-nilai Islam, yang melengket dalam tokoh Ahmad. Nilai agama Islam turut mengatur dan mempengaruhi pertunjukan ini di tengah adegan bernuansa kebudayaan asli. Nilai-nilai Islam tersebut, antara lain: pada babak 1 adegan 2, tersirat dalam dialog Birramen yang mengisahkan orang-orang Makassar di atas perahu, seorang muadjin memanjat tiang mencari arah Barat. Dia memanggil Allah mereka yang Esa. Pada babak 1 adegan 2 tersirat dalam dialog Ahmad bahwa ia tidak takut. Allah Maha Besar. Pada babak 1 adegan 5, tersirat dalam dialog Ahmad bahwa Islam harus ditegakkan.

Ahmad mengajarkan kepada Birramen tentang moralitas kesesuaian yang berupa anjuran, larangan, hak, dan keawajiban yang mendominasi tindakan manusia berdasar nilai-nilai budaya dan agama Islam. Hal ini tersirat dalam adegan ketika pertikaian Birramen dengan Kasim; ketika Kasim meninggal; ketika ketegangan antara orang-orang Makassar dengan orangorang Yolngu; ketika Birramen diputuskan untuk ke Makassar untuk diadili; ketika Birramen berjalan-jalan di pasar; ketika Birramen dibawa ke mesjid untuk diislamkan lalu diajarkan tentang shalat, zikir dan mengaji; ketika Birramen di dalam penjara; dan ketika Birramen keluar dari penjara dan menikah dengan Fatima. Ajaran tentang nilai-nilai ini berjalan secara natural, nonformal, dan berpengaruh besar pada kehidupan Birramen.

Pada babak 2, adegan 1 tersirat dalam tokoh Ahmad memanjat tiang perahu dan melafazkan azan. Ahmad dan Nud melakukan shalat di anjungan perahu dan Ahmad menjadi imam. Birramen hanya bisa mengamati keduanya dari belakang perahu. Selesai shalat, keduanya saling berjabat tangan. Pada saat keduanya menyalami Birramen, tiba-tiba badai datang menghempaskan perahu mereka. Ketiganya lari ke depan dan ke belakang, ke kiri dan ke nanan perahu. Mereka melakukan pertahanan di tengah badai yang mengamuk. Pada saat badai itu Nud membacakan mantara bahari (laut) yang mengandung nilai-nilai Islam dalam bahasa daerah untuk menghentikan badai.

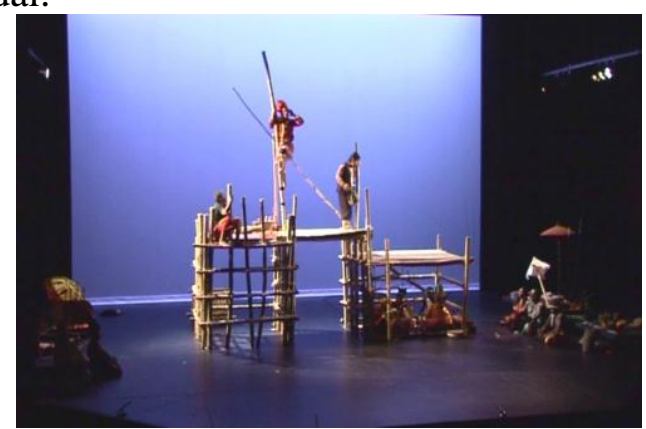

Gambar 5. Bavak 2 adegan 1: Ahmad memanjat tiang perahu dan melakukan azan

(Dok. Asia Ramli)

Ketika Birramen di Makassar, ia dibawa ke mesjid dan diislamkan. Ia diajarkan mengaji, shalat dan zikir. Ia diajarkan tentang konsep akidah tauhid, berserah diri, mensyukuri dan memuji kebesaran Allah SWT. Ajaran-ajaran yang diberikan Ahmad dan Nud kepada Birramen pada dasarnya menyiratkan identitas local Islam - Makassar.

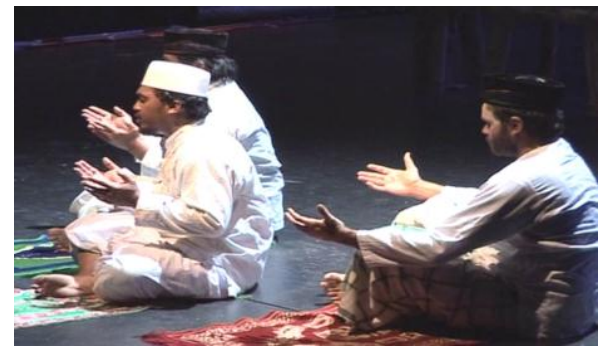

Gambar 6: Babak 2 adegan 3: Ahmad mengajarkan Birramen shalat, zikir dan mengaji

(Dok. Asia Ramli) 
Nilai-Nilai Budaya Makassar dalam Karakter Tokoh Pertunjukan Teater The Eyes Of Marege

\section{PENUTUP}

\section{Pertunjukan teater The Eyes of} Marege kolaborasi Teater Kita Makassar dengan Australian Performing Exhange sarat dengan nilai-nilai budaya Makassar. Nilainilai tersebut dipresentasikan melalui teks dramatic (cerita, tokoh, dialog) dan teks pertunjukan (set panggung, pemeranan, karakter, kostum, properti, musik dan lagu). Melalui simbol atau sistem tanda pada teks dramatic dan teks pertunjukan menunjukkan adanya nilai-nilai budaya Makassar, antara lain: nilai-nilai siri' na pacce, nilai-nilai tausipakatau, nilai-nilai pangngadakkang, dan nilai-nilai islam. Nilai-nilai budaya Makassar ini memperkuat teks dramatic dan teks pertunjukan teater The Eyes of Marege sehingga tema tentang persaudaraan, kegotong-royongan, ikatan perkawinan terejawantah dalam bingkai multicultural dan lintas budaya kedua suku-bangsa Makassar dan Yolngu

\section{DAFTAR PUSTAKA}

Aston, Elaine and George Savona, 1991. Theater As Sign-system: A Semiotic of Text and Performance. London and New York: Routledge.

Effendy, Ridwan. 2005. I Tolok Karya Rahman Arge - Studi Hubungan Antar Teks. Makassar: Intermedia Publishing kerjasama Pustaka Pena Press Makassar.

Hamid, Mattulada, Farid, Lopa, Salombe. 2009. Siri' \& Pacce - Harga Diri Manusia Bugis, Makassar, Mandar, Toraja. Makassar: Pustaka Refleksi.

Janson, Julie. 2007. The Eyes Of Marege terjemahan Henny. Sydney: Australian Performance Exhance Publishers.

Propp, Vladimir. 1975. Morfhology of the Folktale. Austin, London: University of Texas Press.
Rahim, Rahman. 1992. Nilai-nilai Utama Kebudayaan Bugis. Makassar: Hasanuddin University Press.

Said, Nur. 2004. Semiotika Teater. Yogyakarta: Lembaga Penelitian ISI Yogyakarta.

Satoto, Soediro. 1994. Teater Sebagai Sistem Tanda, Sebuah Pengantar dalam Jurnal Masyarakat Seni Pertunjukan Indonesia. Jakarta: Diterbitkan atas kejasama MSPI dengan Gramdia Widiasarana Indonesia.

Taum, Yoseph Yapi. 2011. Studi Sastra Lisan: Sejarah, Teori, Metode, dan Pendekatan Disertai Contoh Penerapannya. Yogyakarta: Lamalera.

Wahid, Sugira. 2008. Manusia Makassar. Makassar: Pustaka Refleksi. 